\title{
METODOLOGIA DE AVALIAÇÃO DO RISCO EM PLANOS DE SEGURANÇA DE ÁGUAS RESIDUAIS. APLICAÇÃO A UM CASO DE ESTUDO.
}

\author{
RISK ASSESSMENT METHODOLOGY IN WASTEWATER SAFETY PLANS. A CASE STUDY
}

\author{
António Sampaio Duarte ${ }^{\mathrm{a}}$, Fernando Castanheira Pinto \\ aUniversidade do Minho, Portugal \\ e-mail: aduarte@civil.minho.pt, castanheirapinto@meo.pt
}

Submissão: 30 de janeiro de 2020 Aceitação: 24 de junho de 2020

\section{Resumo}

Na prossecução dos objetivos do milénio da ONU, o aumento e melhoraria do acesso a sistemas de saneamento básico seguros e sustentáveis continuam a ser uma prioridade de intervenção crítica e essencial para salvaguarda da saúde humana e qualidade de vida das populações. O desenvolvimento, implementação e monitorização de Planos de Segurança, aplicados às diferentes fases do ciclo urbano da água, são uma estratégia crucial, recomendada pela OMS, para prevenção, análise e mitigação do risco associado a perigos e eventos perigosos com impacto nocivo na saúde pública e no meio ambiente. $O$ objectivo deste trabalho é dar um contributo metodológico para a análise do risco em Planos de Segurança de Águas Residuais (PSAR), por meio quer da formulação de um novo método semiquantitativo de avaliação do risco em PSAR e sua aplicação a um caso de estudo, quer de uma abordagem integrada do sistema de saneamento, incluindo as suas interações com a respectiva bacia hidrográfica. Concluiu-se que o nível e tipologia do risco dependem da abrangência geográfica da bacia hidrográfica considerada, a qual influencia não só a diversidade dos perigos e eventos perigosos identificados, mas também a definição das medidas de controle do risco a implementar, resultantes da necessária abordagem de barreiras múltiplas, no sentido de eliminar ou minimizar os riscos para os diversos utilizadores e operadores de um sistema urbano de águas residuais.

Palavras-chave: Saúde pública; planos de segurança de saneamento; sistemas de águas residuais; avaliação do risco.

\section{Abstract}

In pursuit of the UN's millennium goals, increasing and improving access to safe and sustainable sanitation systems remains a critical intervention priority to safeguard human health, life quality and population wellness. The development, implementation and monitoring of Safety Plans, applied to the different sections of the urban water cycle, is a crucial strategy, recommended by WHO, for the prevention, analysis and risk mitigation due to hazards and dangerous events with a harmful impact on public health and the environment. This work intends to make a methodological contribution for risk analysis in Wastewater Safety Plans (WWSP), through a comprehensive approach to the full sanitation system, including its catchment watershed interaction, and the proposal of a new semi-quantitative risk assessment method applied to a case study. It was concluded that the risk level and typology depends on the geographical scope of the considered watershed, which significantly influences not only the diversity of identified hazards and dangerous events, but also the definition of risk control measures to be implemented, arising from a multiple barriers approach, in order to provide a risk mitigation for the several wastewater system users and operators.

Keywords: Public health protection; sanitation safety plans; wastewater systems; risk assessment. 


\section{INTRODUÇÃO}

O crescente afluxo de populações às cidades, aumentando a sua densidade demográfica, tem conduzido ao incremento da poluição e contaminação das origens de água, dificultando ainda mais, num contexto de alterações climáticas, a missão de se garantir o acesso universal a uma água segura (DUARTE, 2007), por meio de estratégias de controle do risco, baseadas numa abordagem de barreiras múltiplas, que mitiguem os impactos nocivos no ambiente e salvaguardem a proteção da saúde púbica.

A gestão integrada das infraestruturas urbanas de água e saneamento é um imperativo e um desafio acrescido para as entidades gestoras, em termos de eficiência, sustentabilidade e qualidade de serviço. À medida que aumenta a pressão da urbanização, a procura de alimentos e a escassez de água, várias entidades e empresas têm desenvolvido modelos de cadeia de valor dos serviços de saneamento tirando proveito dos nutrientes, água e energia de forma a rentabilizar a prestação destes serviços, com benefícios para a saúde pública (remoção de poluentes e dejetos) e a produção de alimentos, pois os efluentes tratados contêm nutrientes que permitem aumentar a produtividade das culturas e reduzir custos, quer com fertilizantes artificiais, quer com a exploração de fontes alternativas de água para rega (OMS, 2015).

Neste contexto, o controle de qualidade dos serviços de saneamento básico ganha uma importância acrescida, devendo basear-se não num procedimento de mera verificação da conformidade legal dos valores paramétricos de indicadores/normas de qualidade da água (no "produto" final), mas, sobretudo, num processo (evolutivo) de gestão do risco com uma abordagem de barreiras múltiplas (OMS, 2004; OMS, 2011), com pontos críticos de controle que permitam detetar precocemente anomalias que potenciem os riscos associados à ocorrência de eventos perigosos previamente identificados.

O desenvolvimento e implementação de Planos de Segurança na gestão do ciclo urbano da água são um desafio emergente, tendo já havido um avanço significativo no caso dos sistemas de abastecimento de água (PSA), face à relevância da qualidade da água para consumo humano na proteção da saúde pública, (e.g., não transmissão de doenças por via hídrica e/ou não ingestão de substâncias nocivas em concentrações tóxicas).

Todavia, a situação relativa aos Planos de Segurança de Saneamento (PSS), que incluem as águas residuais urbanas, é ainda muito incipiente, pelo que justifica um esforço de investigação acrescido, para o qual este trabalho pretende contribuir em termos metodológicos, preconizando uma abordagem abrangente dos sistemas urbanos de águas residuais, que engloba a sua interação com o meio hídrico receptor, onde ocorrem os potenciais impactos nocivos da sua descarga nesse meio hídrico.

$\mathrm{Na}$ Figura 1, representa-se, de forma esquemática, a interação entre PSA e PSS, na visão "tradicional" do ciclo urbano da água (ARAÚJO e VIEIRA, 2016), que não contempla a reutilização das águas residuais tratadas, apesar de esta ser uma prática crescente em todo o mundo, nomeadamente em atividades agrícola, aquícola e de lazer (e.g., campos de golfe).

Os PSS e os PSA apresentam algumas semelhanças conceptuais, em termos de objetivos gerais, etapas processuais estruturantes do seu conteúdo (avaliação do sistema, monitorização e gestão da operação do sistema) e abordagem (sistemática) de gestão do risco por barreiras múltiplas, ao longo do fluxo do processo. Porém, há muitos aspetos diferenciadores que condicionam a conceção desses dois tipos de planos, relacionados com o âmbito:

- da abordagem, que é mais abrangente num PPS, pois além das águas residuais são ainda contemplados dejetos ("excreta") e águas cinzentas, 0 que implica a consideração de outros tópicos associados à proteção do meio ambiente, salubridade ambiental e saúde pública;

- da exposição ao risco, pois nos PSS temos outras vias de exposição (diferentes da ingestão) e múltiplos grupos expostos (além dos consumidores): comunidade local, agricultores e funcionários dos sistemas de recolha e tratamento de águas residuais e resíduos;

- do enquadramento legal/regulamentar, pois num PSS esse enquadramento não está bem definido e há uma fragmentação das tomadas de decisão por diversas entidades 
responsáveis pela elaboração e gestão dos PSS no nível nacional, regional e local (e não apenas no nível da entidade gestora do sistema de abastecimento de água).

\section{Figura 1 - Interação entre PSA e PPS no ciclo urbano da água}

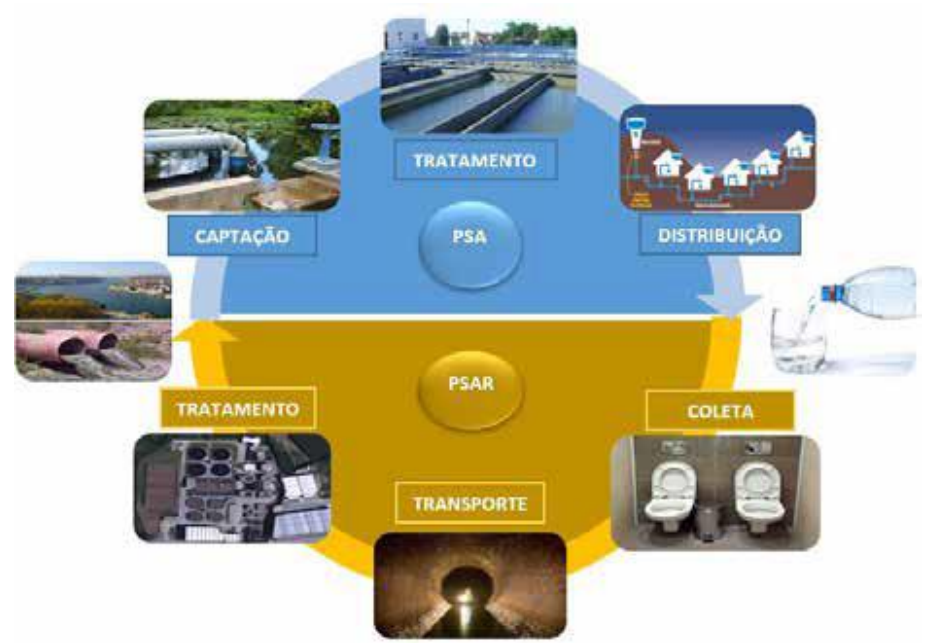

Fonte: Araújo e Vieira (2016).

Em 2006, a Organização Mundial de Saúde (OMS) recomendou que as respetivas Entidades Gestoras (EG) procedessem à implementação de Planos de Segurança de Saneamento na gestão dos seus sistemas que incluíssem os processos de recolha, transporte, tratamento e descarga de águas residuais, de modo a promover a utilização segura dessas águas residuais e seus subprodutos.

Em alternativa à habitual definição de limites para valores paramétricos relativos à qualidade dos efluentes, a OMS preconizou uma maior flexibilidade para selecionar uma gama de opções de prevenção, manuseamento e tratamento (ou não), ao longo do fluxo do sistema, de modo a alcançar os objetivos ambientais e de proteção da saúde pública, reconhecendo o contributo da reutilização para um ciclo urbano da água mais sustentável.

Com efeito, altos níveis de tratamento de águas residuais urbanas nem sempre são viáveis ou o seu custo-benefício pode ser pouco atrativo, justificando, nesses casos, que o uso de efluentes não tratados ou parcialmente tratados e seus subprodutos seja equacionado.

Todavia, a implementação de práticas de reutilização da água de forma sustentada é dificultada quer por deficiente coordenação e inter-operacionalidade das políticas e regulamentações (no nível nacional, regional e local), quer pela complexidade da gestão dos riscos, acrescidos em termos de saúde pública, devido à utilização das águas residuais e de subprodutos em atividades humanas relacionadas com a agricultura e aquicultura. Essa complexidade é ainda mais incrementada quando se adotam estratégias de barreiras múltiplas para prevenir a exposição a agentes patogénicos e substâncias químicas tóxicas (Figura 2).

Os fatores para a definição de critérios do risco passam, em primeiro lugar, pela identificação da natureza e tipos de eventos perigosos, entendidos como um incidente ou situação que ocorre num determinado local, durante um determinado tempo, que pode causar perigos (VIEIRA e MORAIS, 2005), ou seja, o contato com agentes físicos, químicos ou biológicos com impacto direto, no caso dos PSS, na qualidade do efluente tratado e no efeito nocivo da sua descarga nos ecossistemas.

A OMS recomenda a utilização de avaliação quantitativa do risco microbiano (QMRA) para determinar se um esquema de irrigação atende aos padrões de saúde (MOK e HAMILTON, 2014), de modo a salvaguardar os riscos associados à adoção de práticas agrícolas que utilizam águas residuais (parcialmente tratadas) cuja produtividade pode atingir valores 30 a $50 \%$ superiores em relação aos da irrigação tradicional.

No ciclo urbano da água, os eventos perigosos podem ter consequências negativas no 
nível da proteção do ambiente, da saúde humana e da segurança pública.

De uma maneira geral, o processo de gestão do risco envolve vários intervenientes (internos e/ou externos à entidade) e desenvolve-se em várias fases, destacando-se as de apreciação (identificação, análise e avaliação) e de tratamento do risco (Figura 3). Esta metodologia é adotada na elaboração de PSA com as devidas adaptações à produção de água para consumo humano (VIEIRA, 2005).

Figura 2 - Estratégia de barreiras múltiplas na gestão do risco em PSS

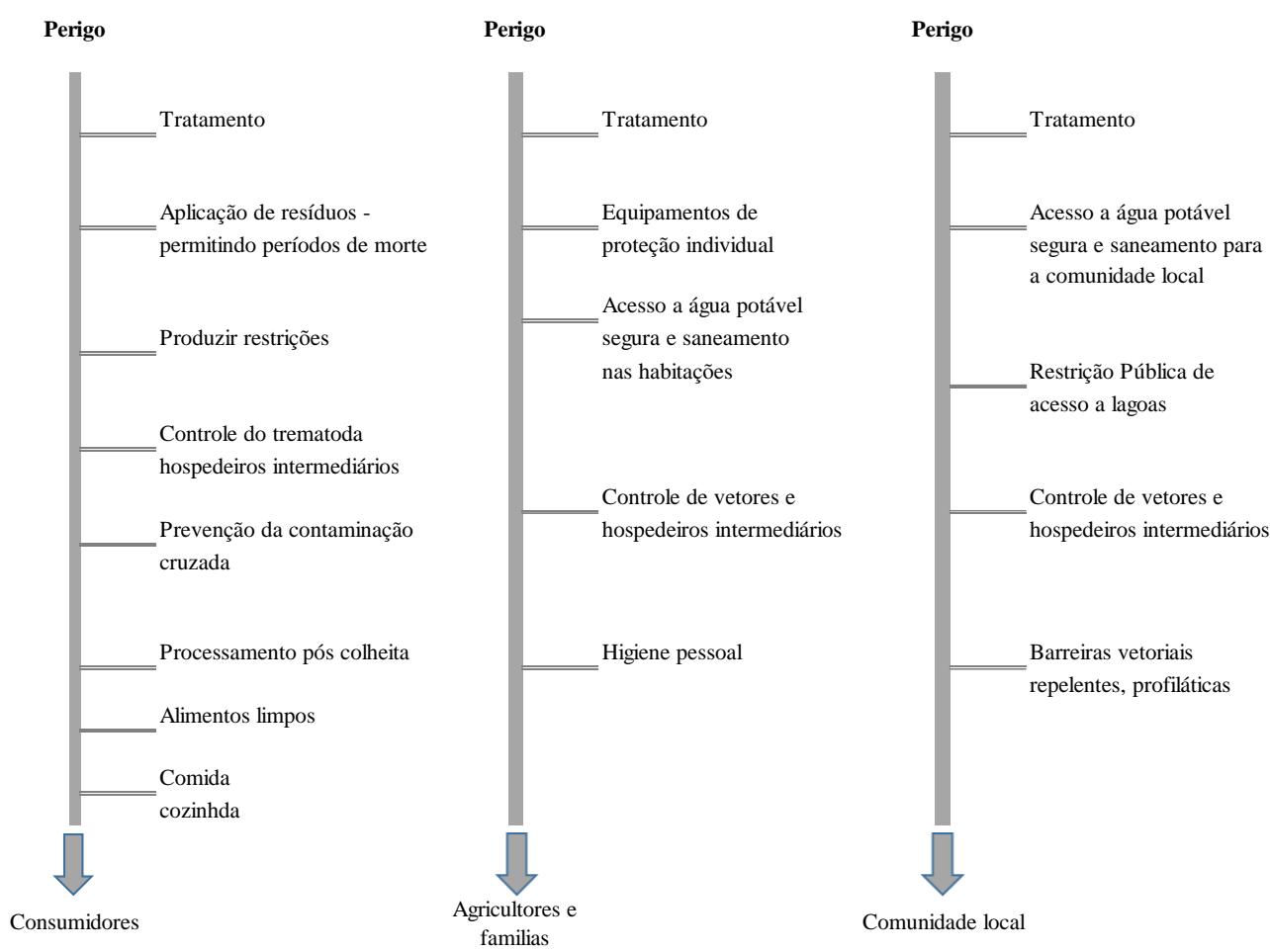

Fonte: adaptada de OMS (2006).

Figura 3 - Fluxograma dum processo de gestão do risco

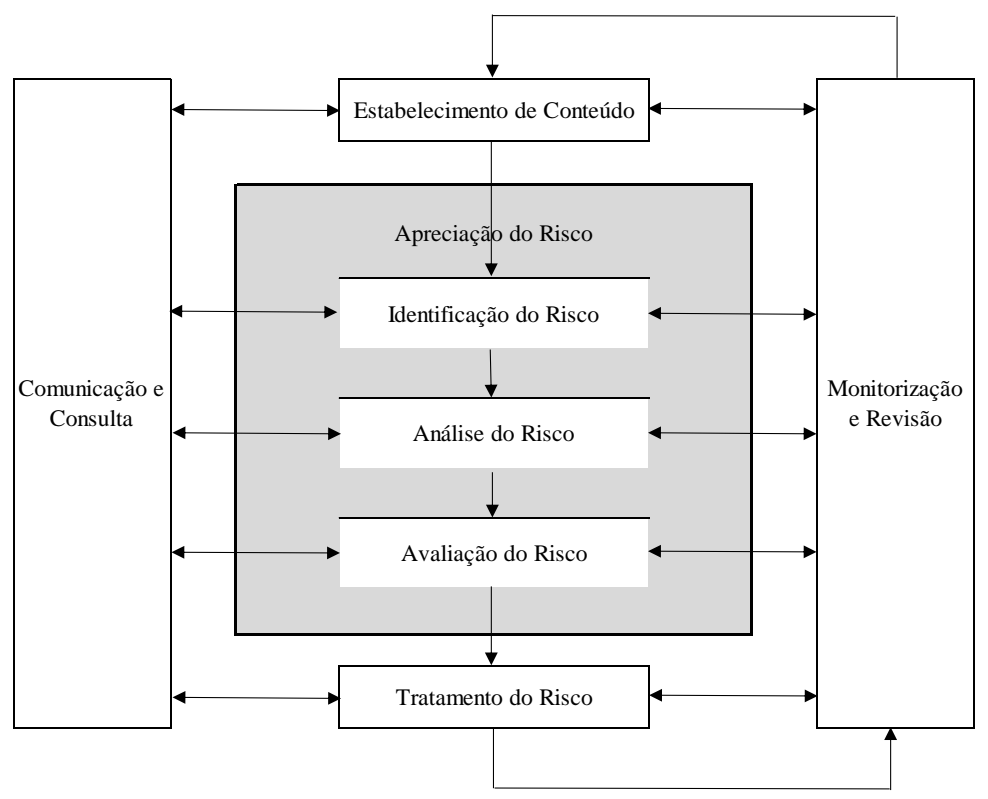

Fonte: adaptada de Norma NP ISSO 31000 (2012). 
Para a análise do risco, é necessário estabelecer critérios para definir a probabilidade e o grau de severidade associada a cada evento perigoso (e/ou suas combinações), bem como a forma de determinação do nível de risco e os critérios que classificam um dado nível como aceitável ou tolerável. Existem vários métodos para a análise do risco (e.g., análise multicritério, qualitativos, quantitativos, semiquantitativos), sendo estes últimos os mais adequados para a análise do tipo de riscos em sistemas urbanos de água e similares, em que habitualmente não existem históricos de dados suficientemente consistentes.

Por essa razão, o método desenvolvido neste trabalho é semiquantitativo, baseando-se numa estimativa especializada da probabilidade da ocorrência de um evento e na severidade das suas consequências, cujo produto permite obter, de forma fácil e rápida, uma matriz de nível do risco (quantitativo) que evidencia o quadrante dos riscos mais críticos para os sistemas em análise (BOŽEK e URBAN, 2008). Os critérios adotados para a definição da severidade visam uma aplicabilidade essencialmente direcionada para a salvaguarda da saúde pública.

O tratamento do risco implica um processo cíclico de seleção de uma ou mais opções de medidas ou ações para modificar (controlar) o nível do risco, bem como a sua implementação. Sempre que o nível de risco for superior a "moderado", deverão ser implementadas ações imediatas para o reduzir até um nível considerado aceitável.

O objetivo principal deste artigo é dar um contributo para 0 desenvolvimento de instrumentos essenciais no apoio à tomada de decisão pelas entidades gestoras (EG) dos sistemas de águas residuais, por meio não só da apresentação de uma metodologia "inovadora" de avaliação do risco, que tem também em consideração a magnitude dos impactos de eventos perigosos, mas também da priorização do nível do risco associado a cada evento perigoso e perigo existente, para estabelecer a premência/urgência das necessárias medidas/ações de controle (PINTO, 2018). Para validação desta metodologia, efetuou-se a sua aplicação a um caso de estudo: o sistema de águas residuais da cidade de Vila Real (SARVR), em Portugal, incluindo a sua interação com o meio hídrico receptor (rio Corgo).

\section{METODOLOGIA}

O Plano de Segurança de Águas Residuais (PSAR) é uma ferramenta essencial para se alcançarem bons resultados no nível da qualidade das descargas de águas residuais, uma vez que, tal como os PSA, incorpora metodologias de avaliação e gestão dos riscos ao longo do processo de recolha, transporte e tratamento de águas residuais, constituindo uma análise sistemática dos perigos para a saúde pública existentes no Sistema e dos processos de gestão necessários ao seu efetivo controle, garantindo a qualidade das descargas de água residual tratada.

Os conceitos de coordenação e melhoria contínua são fundamentais nos PSAR, os quais deverão ser estruturados de acordo com as seis etapas representadas na Figura 4).

Do desenvolvimento e implementação de um PSAR, de acordo com esta estruturação, devem resultar benefícios relevantes decorrentes das seguintes ações:

- identificação de perigos e eventos perigosos ao longo do SAR, permitindo escalonar e hierarquizar os riscos a eles associados;

- elaboração de planos de melhoria e sua monitorização, tendo como objetivo a redução do risco para níveis considerados aceitáveis;

- mitigação dos riscos para a saúde pública e o ambiente decorrentes da recolha (coleta), tratamento, reutilização e eliminação de resíduos (em contextos formais ou informais);

- proteção da saúde dos consumidores no que respeita ao consumo de vegetais, se provenientes de explorações onde os agricultores utilizam efluente reutilizado;

- promoção da segurança dos operadores do sistema, garantindo a sua integridade e proteção, dada a sua maior exposição durante o transporte e distribuição de água residual tratada.

Nos pontos seguintes, serão apresentados os procedimentos referentes a cada um dos tópicos dum PSAR e sua ilustração, quando pertinente, com os elementos relativos ao caso de estudo (SARVR).

\subsection{Descrição do sistema de águas residuais (SAR)}


Em cada zona do sistema de águas residuais, a definição da área de atuação visa identificar as atividades e locais de intervenção prioritária por apresentarem maior risco para a saúde pública. Tal seleção deve ter em consideração questões como: o desempenho dos SAR, com particular ênfase para os fluxos que recebem tratamento inadequado (e.g., efluentes hospitalares $e$ industriais) e que podem apresentar um risco elevado ou situações recorrentes de anomalias nas redes de drenagem (e.g., obstrução de coletores e avaria em estações elevatórias); a gestão de lamas (localização da produção, descarga e sua utilização); e a gestão de águas residuais não tratadas ou parcialmente tratadas (alta pluviosidade), incluindo a avaliação do impacto da sua descarga no meio hídrico receptor.

Os fatores territoriais mais relevantes para a definição dessas zonas de atuação prioritária são: áreas de elevada densidade populacional, inundáveis ou ocupadas por populações mais vulneráveis (habitação social ou precária); áreas com registro ou suspeita de prevalência de doenças relacionadas com a presença de águas residuais (e.g., helmintíase, infecções por protozoários intestinais); origens de água com descarga de efluentes tratados a montante, áreas de lazer (e.g., praias fluviais); áreas com atividade agricultura ou aquicultura onde são reutilizadas águas residuais.

A descrição detalhada do SAR e dos seus requisitos de desempenho e operacionais é um suporte fundamental para 0 subsequente processo de análise e avaliação do risco, dado que cada sistema é único e tem as suas especificidades próprias, tanto nos sistemas locais de saneamento (descentralizados) como nos sistemas convencionais (centralizados) de drenagem e tratamento de águas residuais.

\section{Figura 4 - Planeamento da segurança em sistemas urbanos de saneamento}

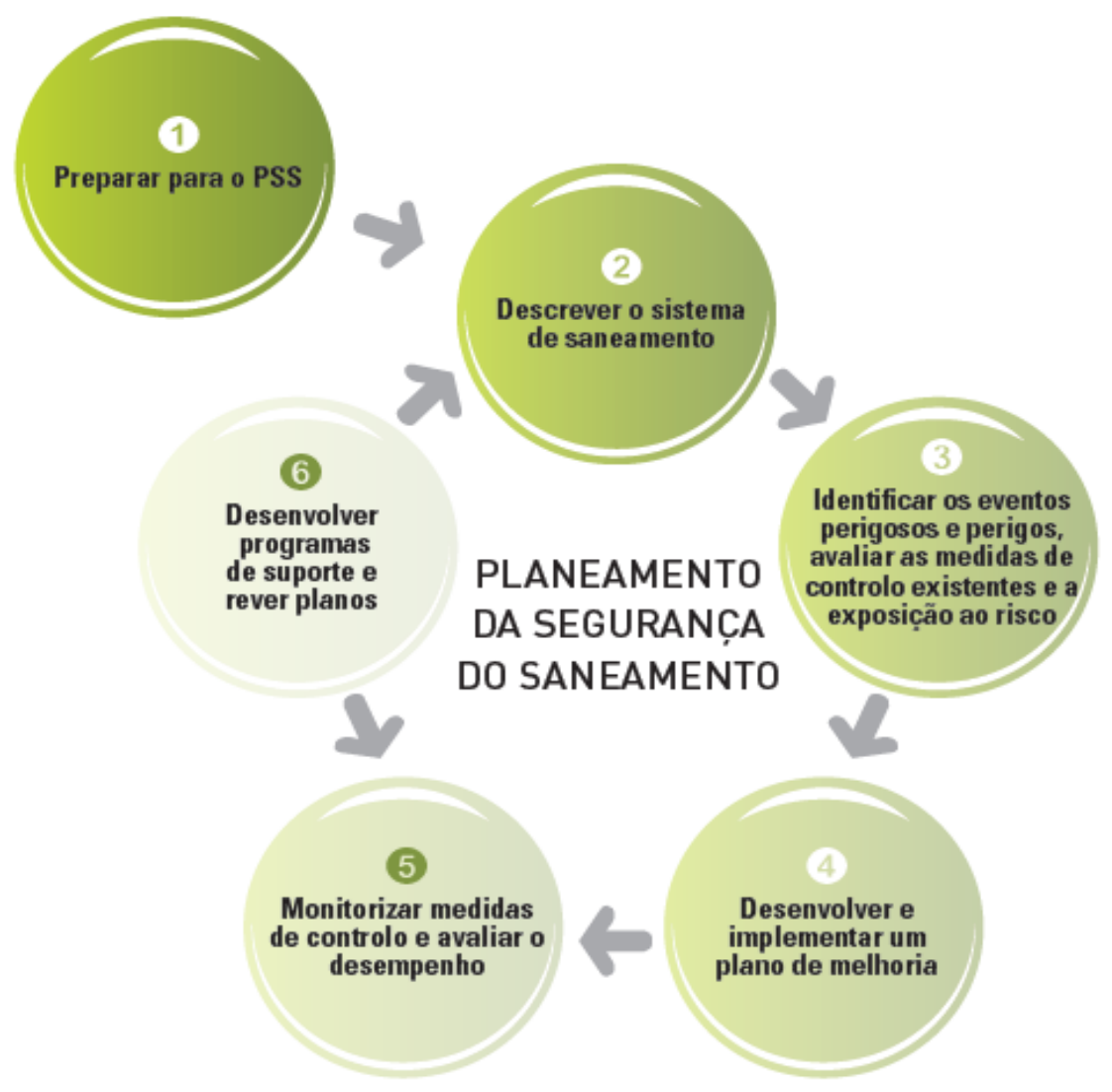

Fonte: adaptada de OMS (2015). 
O método selecionado para elaborar o mapeamento dum sistema depende da sua dimensão e complexidade, sendo habitualmente adotado um diagrama de fluxo que inclua todas as etapas do processo (drenagem, tratamento, rejeição, reutilização), para permitir uma identificação e apreciação global das componentes desse SAR. Na Figura 5, apresenta-se o exemplo do mapeamento de um sistema "em alta", isto é, após as redes de coletores (sistema "em baixa").

O mapa do sistema deve representar os fluxos e variabilidade das frações líquida, sólida e gasosa (e.g., $\mathrm{H}_{2} \mathrm{~S}, \mathrm{CH}_{4}, \mathrm{CO}_{2}$ ) desde a sua produção até ao seu uso ou descarte
(STENSTRÖM et al., 2011), sendo também relevante a sistematização da informação relativa a diferentes tipos do sistema de drenagem de águas residuais (separativo, unitário e misto).

A identificação, tipificação e dimensão dos grupos de pessoas potencialmente expostas a perigos e eventos perigosos são imprescindíveis para a prossecução do principal objetivo dum PSAR: a salvaguarda da saúde pública e bemestar das populações. A categorização das pessoas que podem estar expostas a um dado perigo permite uma posterior priorização das estratégias de controle do risco em função quer do seu nível quer da vulnerabilidade e magnitude dos potenciais grupos expostos.

\section{Figura 5 - Diagrama de sistemas de água residuais "em alta" (sem redes de drenagem)}

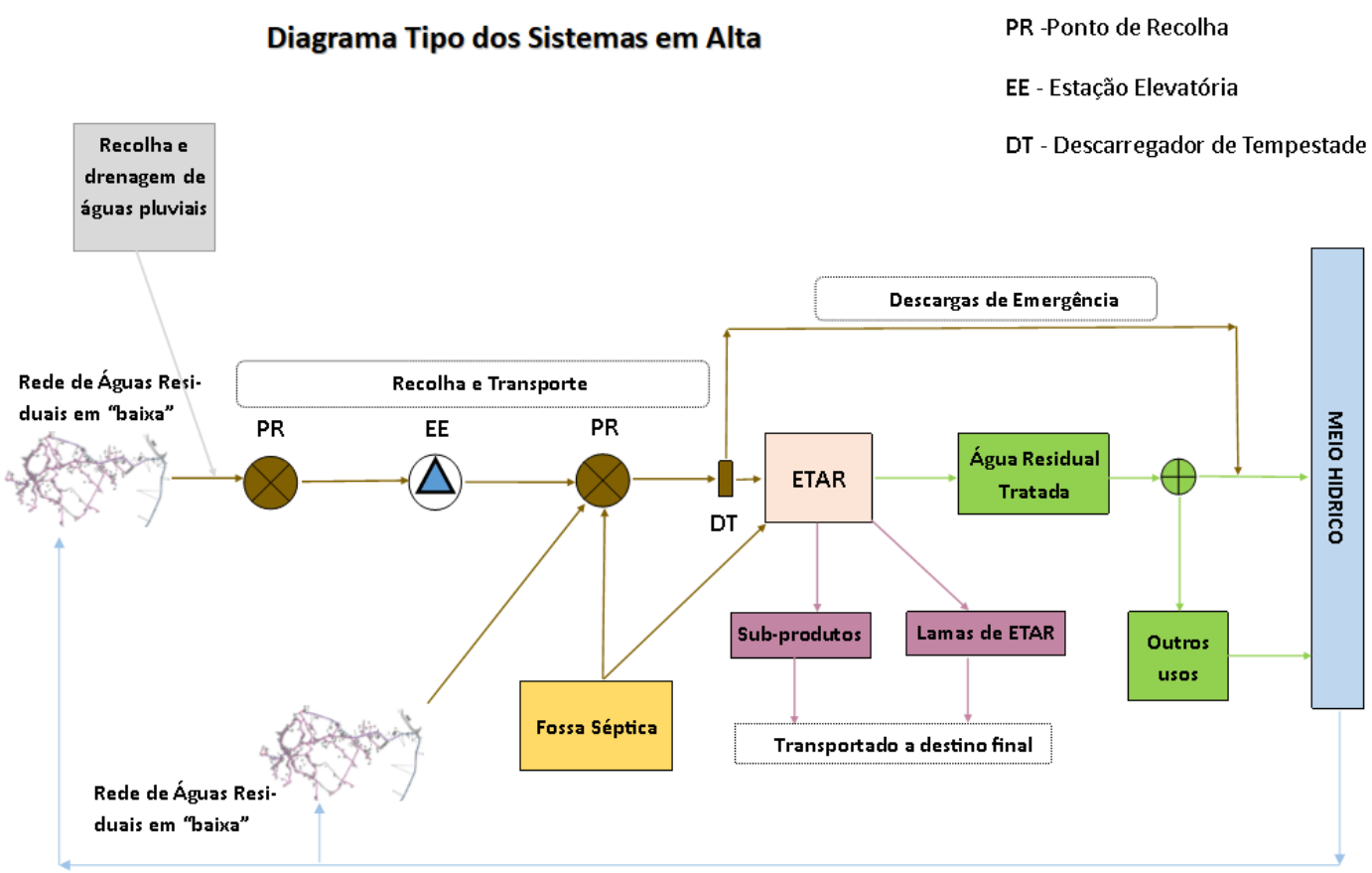

Fonte: Pinto (2018).

No Quadro 1, apresenta-se um exemplo das categorias de grupos expostos a riscos, habitualmente consideradas em PSAR. Essas categorias de grupos são posteriormente adicionadas ao mapa do sistema, por meio da simbologia indicada nesse quadro.

O método selecionado para elaborar o mapeamento dum sistema depende da sua dimensão e complexidade, sendo habitualmente adotado um diagrama de fluxo que inclua todas as etapas do processo (drenagem, tratamento, rejeição, reutilização), para permitir uma identificação e apreciação global das componentes desse SAR. $\mathrm{Na}$ Figura 5, apresenta-se o exemplo do mapeamento de um sistema "em alta", isto é, após as redes de coletores (sistema "em baixa").

\subsection{Identificação de perigos e eventos perigosos}

A informação constante da descrição do sistema (mapeamento), o conhecimento das várias frações de resíduos (líquidos, sólidos e 
gasosos) e a identificação dos grupos expostos constituem os principais requisitos para a identificação dos eventos perigosos e dos perigos num SAR, relacionados com a inadequada qualidade do efluente tratado e/ou com a eventual ocorrência de descargas acidentais ou anormais que eventualmente possam ocorrer no Sistema.

Quadro 1 - Identificação e descrição dos grupos expostos a perigos num PSAR

\begin{tabular}{|c|c|c|c|}
\hline Grupo exposto & & Simbolo & Descrição \\
\hline Comunidade Local & $\mathbf{R}$ & & $\begin{array}{l}\text { Pessoas que vivem nas imediações das instalações de recolha, tratamento ou a } \\
\text { jusante da descarga. Consideram-se as que são suscetiveis de ser afetadas de } \\
\text { uma forma passiva, quer pelo sistema quer pelos produtos e residuos resultantes } \\
\text { da utilização das águas residuais tratadas }\end{array}$ \\
\hline Trabalhadores & C & & $\begin{array}{l}\text { Pessoas que trabalham na exploração do sistema, nomedamente os que se } \\
\text { encontram afetos ao controlo da rede de recolha, processo de tratamento ou } \\
\text { manutenção de instalações e equipamentos. Incluem-se os que manipulam } \\
\text { qualquer fração de residuos, sejam internos ou externos à empresa }\end{array}$ \\
\hline Agricultores & A & & $\begin{array}{l}\text { Pessoas que utilizam água residual tratada ou semitratada, linhas de água onde } \\
\text { as mesmas são descarrregadas ou subprodutos do tratamento, nomeadamente } \\
\text { compostos de lamas de ETE's }\end{array}$ \\
\hline Consumidores & $\mathbf{U}$ & & $\begin{array}{l}\text { Pessoas que consomem ou utilizam produtos que são produzidos usando } \\
\text { recurso aos subprodutos ou águas residuais, nomeadamente a rega }\end{array}$ \\
\hline
\end{tabular}

Nessa identificação, são considerados todos os potenciais perigos biológicos, físicos e químicos suscetíveis de estarem associados a um dado sistema de águas residuais. Os perigos biológicos estão associados à presença de microrganismos patogénicos (e.g., bactérias, vírus, protozoários, cistos), em concentrações que possam constituir ameaças para a saúde humana. Os perigos químicos estão geralmente ligados à presença de substâncias indesejáveis, que, em concentrações tóxicas, são nocivas para a saúde, ou que, mesmo em baixas concentrações, constituem um potencial perigo devido a propriedades de bioacumulação nos seres vivos. Os perigos físicos estão geralmente relacionados com as propriedades organolépticas do esgoto (e.g., cor, odor, turbidez) ou à presença de sólidos de dimensão considerável e de objetos perfurantes que possam ameaçar a integridade física dos operadores.

$\mathrm{Na}$ identificação dos perigos e eventos perigosos em PSAR, a componente do meio hídrico receptor deve ser sempre incorporada nos mesmos, face à possibilidade de existência (presente ou futura) de captações de água (abastecimento, rega, aquicultura) e de áreas de lazer (praias fluviais e marítimas), sujeitas aos impactos negativos de descargas de esgoto (mesmo que tratado) na saúde pública. A avaliação do risco nessa componente ambiental implica necessariamente a inclusão de modelos de simulação do impacto ecológico dessas descargas nesses meios hídricos.

Na Quadro 2, apresenta-se, como exemplo, um modelo estrutural para 0 registo de informação relativa a diferentes fases do processo de gestão do risco (PINTO, 2018), que se inicia na identificação do risco (definição de perigos e eventos perigosos) e termina com a descrição de medidas de controle para tratamento de riscos, sinalizados com um nível não aceitável (crítico) no processo de avaliação do risco.

A exposição persistente a agentes biológicos encontrados na atmosfera pode causar reações alérgicas ou mesmo infeções no ser humano, provocando sintomatologias diversas (e.g., tosse, falta de ar, tonturas, letargia, febre e problemas digestivos). Em particular, a exposição nociva a toxinas produzidas por alguns microrganismos, que podem desenvolver-se em sistemas de ventilação (aquecimento, arrefecimento e desumidificação) de edifícios onde a manutenção seja deficiente, não deverá ser descurada. A dimensão celular dos patogénicos é um fator importante na determinação do risco, que é geralmente superior para agentes de menor dimensão, devido ao facto de as células mais pequenas e os esporos ficarem alojados no tecido pulmonar e não serem facilmente expelidos (RIBEIRO, 2017). 
Quadro 2 - Modelo de registo da informação relativa a fases do processo de gestão do risco

\begin{tabular}{|c|c|c|c|c|c|c|c|c|c|c|c|c|c|}
\hline \multirow[b]{2}{*}{$\begin{array}{l}\text { ETAPA } \\
\text { (1) }\end{array}$} & \multicolumn{5}{|c|}{ Identificação do Perigo } & \multicolumn{5}{|c|}{ Avaliação de Risco } & \multicolumn{2}{|c|}{ Medidas de Controlo } & \multirow[b]{2}{*}{ Observação } \\
\hline & \begin{tabular}{|c} 
Tipo de \\
Risco \\
(2)
\end{tabular} & $\begin{array}{c}\text { Grupo } \\
\text { Exposto }\end{array}$ & Evento Perigoso & Perigo & $\begin{array}{c}\text { Via de } \\
\text { Exposição }\end{array}$ & $\begin{array}{c}\text { Prob. } \\
\text { (3) }\end{array}$ & $\begin{array}{l}\text { Sev. } \\
(4)\end{array}$ & $\begin{array}{l}\text { Magn. } \\
\text { (5) }\end{array}$ & $\begin{array}{l}\text { Pont. } \\
\text { (6) }\end{array}$ & $\begin{array}{l}\text { Nivel } \\
\text { Risco } \\
\text { (7) }\end{array}$ & $\begin{array}{l}\text { Identificação da } \\
\text { medida de } \\
\text { controlo } \\
\text { existente(s) }\end{array}$ & Validação & \\
\hline & & & & & & & & & & & & & \\
\hline
\end{tabular}

\subsection{Avaliação do risco}

De acordo com a nova metodologia de avaliação aqui proposta, o nível do risco $(R)$ será determinado por meio da multiplicação da classificação atribuída, não apenas à probabilidade $(P)$ e severidade $(S)$ do evento (usada nos PSA), mas também a uma terceira variável que representa a magnitude $(\mathrm{M})$ de cada um dos grupos potencialmente expostos a esse evento.

A introdução desta nova variável, no cálculo do nível do risco em PSAR, resulta do fato de ser necessário caraterizar a dimensão do risco circunscrito a diferentes categorias (grupos e subgrupos) de população exposta, dado existirem riscos diferenciados resultantes de diferentes níveis de severidade ou probabilidade de ocorrência dum dado evento. Além disso, ao refinar 0 processo de seriação/diferenciação proveniente do cálculo do nível do risco, permitese que cada medida de controle possa ser diferenciada, não apenas de acordo com o tipo de perigo (biológico, químico ou físico), mas também com a especificidade do subgrupo exposto.

O Quadro 3 apresenta os critérios de classificação da probabilidade que foram usados no caso de estudo (SAR de Vila Real), sendo elaborado com um escalonamento que permite atribuir uma classificação coerente com o que na realidade "aconteceu" ou possa vir a "acontecer", mesmo na ausência de dados históricos consistentes e/ou objetivos, como ocorre, frequentemente, com a informação relativa a sistemas de tratamento de águas residuais. A classificação de "quase certo", com pontuação máxima de 8 , pretende acentuar e valorar a "certeza" do acontecimento, conferindo-lhe um efeito relevante no resultado que atribui a classificação do nível do risco dum dado evento ou perigo.

No Quadro 4, são apresentados os critérios (especificamente adaptados para este trabalho e aplicados no caso de estudo) para a definição do nível de severidade, que foi associado ao grau de dano ou consequência para a saúde humana causado por um determinado perigo ou evento.

Os critérios para a classificação do novo parâmetro (a magnitude) tiveram de ser definidos de raiz, de modo a estabelecer uma gradação da dimensão ou expressão quantitativa que determinado perigo ou evento tem num determinado grupo exposto (Quadro 5).

O nível de risco $(R)$ resulta do produto das três variáveis aqui consideradas e pode ser representado tridimensionalmente por meio de um "cubo" de priorização do risco, ou bidimensionalmente por meio de diferentes matrizes de priorização do risco, considerando uma das variáveis com valor constante.

\section{Quadro 3 - Classificação da Probabilidade (P) e seus critérios}

\begin{tabular}{|c|l|l|}
\hline \multicolumn{2}{|c|}{ Classificação } & Descrição \\
\hline 1 & Muito Improvável & Não aconteceu no passado e não é espectável que ocorra no futuro mesmo em condições excepcionais \\
\hline 2 & Improvável & Não aconteceu no passado, mas pode ocorrer em condições excecionais no futuro. \\
\hline 3 & Possível & Pode ter acontecido no passado ou pode ocorrer em condições normais no futuro. \\
\hline 5 & Provável & Foi observado no passado e pode continur a ocorrer no futuro em condições normais. \\
\hline 8 & Quase certo & Tem sido frequentemente observado no passado e continuará a ocorrer no futuro em condições normais. \\
\hline
\end{tabular}




\section{Quadro 4 - Classificação da Severidade (S) e seus critérios}

\begin{tabular}{|c|l|l|}
\hline \multicolumn{2}{|c|}{ Classificação } & \multicolumn{1}{c|}{ Descrição } \\
\hline 1 & Insignificante & Perigo ou evento perigoso de efeito, na saúde, nulo ou negligenciável. \\
\hline 2 & Ligeira & $\begin{array}{l}\text { Perigo ou evento perigoso que potencialmente tem, na saúde, efeitos agudos (e.g., irritação na pele, náusea, dor de } \\
\text { cabeça). }\end{array}$ \\
\hline 4 & Moderado & $\begin{array}{l}\text { Perigo ou evento perigoso que potencialmente poderá ter um efeito, na saúde, limitado no tempo, ou causar uma } \\
\text { doença ligeira (e.g., diarreia aguda, vómitos, infeção do trato respiratório superior, pequeno traumatismo), sem } \\
\text { necessidade de hospitalização. }\end{array}$ \\
\hline 8 & Grave & $\begin{array}{l}\text { Perigo ou evento perigoso que potencialmente poderá resultar em doença ou lesão (e.g., diarreia crónica, } \\
\text { problemas respiratórios crónicos, doenças neurológicas, fratura óssea), que requer hospitalização. }\end{array}$ \\
\hline 16 & Mortal ou Catastrófico & $\begin{array}{l}\text { Perigo ou evento perigoso que potencialmente poderá resultar em doença ou lesão grave, ou mesmo a morte (e.g., } \\
\text { envenenamento grave, perda de extremidades, queimaduras graves, afogamentos); }\end{array}$ \\
\hline
\end{tabular}

Quadro 5 - Classificação da Magnitude (M) e seus critérios

\begin{tabular}{|l|l|l|}
\hline \multicolumn{2}{|c|}{ Classificação } & Descrição \\
\hline 1 & Muito Reduzida & Afeta menos de $10 \%$ do grupo exposto \\
\hline 3 & Reduzido & Afeta mais de $10 \%$ e menos de $20 \%$ do grupo exposto \\
\hline 6 & Médio & Afeta mais de $20 \%$ e menos de $50 \%$ do grupo exposto \\
\hline 9 & Eevado & Afeta mais de $50 \%$ e menos de $90 \%$ do grupo exposto \\
\hline 12 & Muito Elevado & Afeta mais de $90 \%$ do grupo exposto \\
\hline
\end{tabular}

\subsection{Tipificação de medidas de controle a incorporar nos Planos de Melhorias}

$\mathrm{Na}$ sequência das etapas anteriores (identificação e avaliação do risco), que conduzem à categorização qualitativa do nível do risco de perigos e ou eventos perigosos, seguese o tratamento do risco com a tipificação e priorização das medidas de controle (Figura 6) a implementar em Planos de Melhorias, sem excluir a inclusão de eventuais medidas excecionais/avulsas para casos específicos e particulares.

O objetivo do Plano de Melhorias é o de incorporar opções para a implementação (a curto, médio e longo prazo) de ações de gestão que reduzam os riscos críticos dum perigo ou evento perigoso para níveis aceitáveis, por meio de medidas de controle (infraestruturais, operacionais, gestão), adoção de alternativas tecnológicas, não tecnológicas ou comportamentais, em diferentes locais ao longo do sistema de águas residuais (SAR).

Figura 6 - Tipificação de ações e medidas de controle

\begin{tabular}{|c|l|l|}
\hline Pontuação & \multicolumn{1}{|c|}{ Nivel } & \multicolumn{1}{c|}{ Medidas } \\
\hline [1;30[ & Insignificante & Não é necessário implementar medidas de controlo; o risco deve ser monitorizado. \\
\hline [30;60[ & Baixo & $\begin{array}{l}\text { Não precisam de ser implementadas medidas de controlo. Podem ser mantidas, se } \\
\text { existirem, com a demonstração da análise custo-benefício, ou seja se os benefícios } \\
\text { superarem os custos. O risco deve ser constantemente monitorizado. }\end{array}$ \\
\hline [60;120[ & Moderado & $\begin{array}{l}\text { Não é necessário implementar novas medidas de controlo. Recomenda-se propor } \\
\text { medidas se não existirem, para reduzir os riscos, para o qual a análise custo-benefício } \\
\text { demonstra que os benefícios superam os custos. O risco deve ser monitorizado } \\
\text { permanentemente. }\end{array}$ \\
\hline [120;360[ & Elevado & $\begin{array}{l}\text { É necessário atuar de imediato com a implementação de medidas de controlo por um } \\
\text { determinado prazo. A atividade sem redução de risco só pode ser operada se for } \\
\text { socialmente muito significativa. O custo da redução do risco deve ser proporcional ao } \\
\text { valor dos ativos protegidos. Novamente, recomenda-se a utilização da análise custo- } \\
\text { benefício para avaliar a eficiência da adoção de medidas de controlo específicas. }\end{array}$ \\
\hline$\geq 360$ & Excepcional & $\begin{array}{l}\text { É necessário interromper a atividade ou implementar imediatamente novas medidas de } \\
\text { controlo destinadas à minimização do risco. }\end{array}$ \\
\hline
\end{tabular}


Sempre que possível, o Plano de Melhorias deve intervir na causa do problema de forma a prevenir, reduzir ou minimizar a sua ocorrência e selecionar medidas que por si só possam mitigar os efeitos da combinação de eventos perigosos. $\mathrm{Na}$ Figura 7, apresenta-se um modelo de referência relativo aos tópicos a considerar no desenvolvimento dum Plano de Melhorias.

Figura 7 - Modelo estrutural para o desenvolvimento de Planos de Melhorias

\begin{tabular}{|c|c|c|c|c|c|c|c|c|c|c|c|}
\hline \multirow[b]{2}{*}{ ETAPA } & \multicolumn{4}{|c|}{ Identificação do Perigo } & \multirow{2}{*}{$\begin{array}{l}\text { Medidas de Controlo Inicial } \\
\begin{array}{c}\text { Identificação da medida de } \\
\text { controlo existente(s) }\end{array}\end{array}$} & \multicolumn{6}{|c|}{ Alternativas para o plano de melhoria } \\
\hline & $\begin{array}{l}\text { Tipo de } \\
\text { Risco }\end{array}$ & $\begin{array}{c}\text { Grupo } \\
\text { Exposto } \\
\end{array}$ & Evento Perigoso & Perigo & & $\begin{array}{c}\text { Medida de controlo } \\
\text { possivel }\end{array}$ & Comentários & $\begin{array}{c}\text { Eficácia da alternativa } \\
\text { na redução do risco }\end{array}$ & $\begin{array}{c}\text { Referência/ } \\
\text { validação }\end{array}$ & Prioridade & Responsável \\
\hline & & & & & & & & & & & \\
\hline
\end{tabular}

No âmbito deste trabalho, foi efetuada uma caracterização preliminar da situação de referência relativa ao estado químico e biológico do meio hídrico receptor, por meio da realização de campanhas de amostragem, desde a nascente até à foz do rio Corgo, na época de estiagem (a mais crítica), de modo a sustentar uma futura avaliação do risco ambiental resultante da descarga de efluentes, aplicando modelos de simulação da dispersão de poluentes nesse sistema hídrico, nomeadamente, a jusante das descargas existentes nesta bacia hidrográfica.

Com efeito, um PSAR só ficará completo com a integração dessa componente complementar de avaliação de riscos num sistema, fundamental para a definição e priorização de medidas operacionais, nos sistemas de tratamento que permitam mitigar os potenciais riscos para a saúde pública.

A metodologia utilizada na campanha de amostragem teve como princípio avaliar os valores da temperatura, $\mathrm{pH}, \mathrm{OD}$, azoto, fósforo, coliformes totais e coliformes fecais, quer no efluente de cada uma das 10 ETEs, quer no meio hídricoreceptor a montante e a jusante dessas descargas.

\section{RESULTADOS E DISCUSSÃO}

Os resultados referem-se quer à nova metodologia de avaliação do risco desenvolvida para PSAR, quer à sua incorporação num Plano de Segurança aplicado a um caso de estudo: o SAR de Vila Real, no norte de Portugal, caracterizado por uma área aproximada de 35100 ha, servindo 102 aglomerados populacionais, pertencentes a 20 freguesias (bairros), com uma população total estimada de 32.500 habitantes.

\subsection{Matrizes de priorização do risco}

A matriz de priorização do risco, utilizada em muitos planos de segurança da água (PSA), teve a sua origem na metodologia semiquantitativa proposta nas normas Standars Australia e Standards New Zealand (AS/NZS, 2004; VIEIRA, 2005; BARTRAM, 2019), em que os parâmetros probabilidade e severidade das ocorrências são pontuados usando uma mesma escala, com valores de 1 a 5 .

A elevada subjetividade e incerteza associada à atribuição destas pontuações originou a procura de metodologias alternativas baseadas e validadas na opinião de especialistas e técnicos do sector da água, visando uma ponderação dos próprios objetivos de saúde pública. Neste contexto, surgiu uma metodologia de avaliação do risco em PSA (BEZERRA, 2018), usando uma matriz semiquantitavia de priorização do risco em que o grau de severidade de uma ocorrência é expresso por meio de uma escala em progressão geométrica de razão dois, mantendo-se a razão unitária para a escala da probabilidade/frequência.

$\mathrm{Na}$ nova metodologia de avaliação do risco, desenvolvida para aplicação em PSAR (PINTO, 2018), além de se usarem diferentes escalas para cada um desses parâmetros, em que a da severidade é idêntica à usada por Bezerra (2018) e a da probabilidade é diferente da proposta por Bartram (2009), introduziu-se uma terceira variável (magnitude) para traduzir a dimensão da população de cada uma das categorias consideradas, além da dos consumidores (que é a única no caso dos PSA). A representação simultânea das pontuações obtidas para o nível do risco $(R)$, resultante do produto dessas três variáveis, pode ser traduzida de forma 
tridimensional por meio de um "cubo" de priorização do risco (Figura 8).

Todavia, de modo a tornar mais clara a perceção gráfica e a análise do contributo das diferentes variáveis e categorias do risco consideradas, podem ser extraídas várias matrizes de priorização do risco, mantendo uma das variáveis constante. Na Figura 9, apresentase, como exemplo, as matrizes do risco correspondentes a perigos ou eventos com probabilidades de ocorrência classificadas com nível 5 e 8, de modo a evidenciar uma situação com grande amplitude de níveis do risco.

Estas matrizes foram setorizados (coloração) para permitir um escalonamento qualitativo do nível do risco, em função das pontuações obtidas e de acordo com o critério definido na tabela dessa figura, que servirá para identificar as situações de risco crítico e a priorização das medidas de melhoria a implementar.

Figura 8 - Representação tridimensional do nível do risco ("cubo" de priorização do risco)

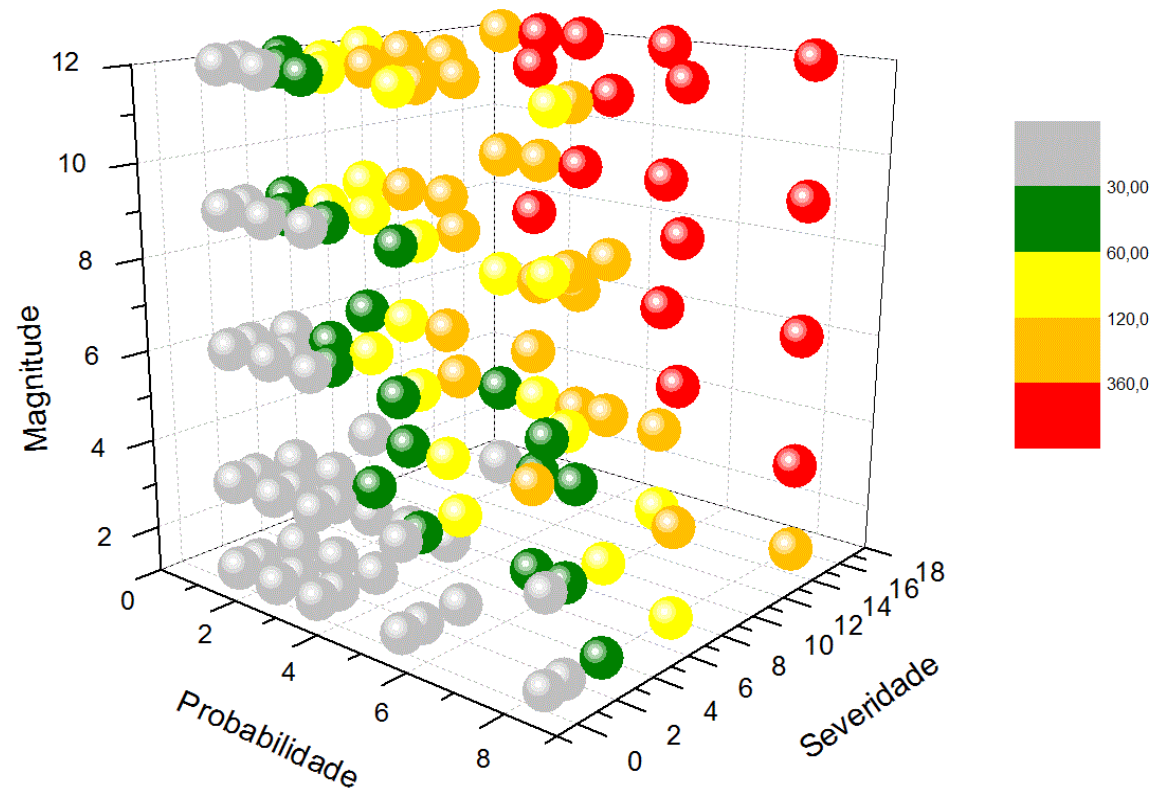

Figura 9 - Matrizes e categorias do risco

\begin{tabular}{c|cccccccccc} 
& $(\mathrm{P}=5)$ & \multicolumn{1}{c}{$(\mathrm{P}=8)$} \\
$\mathrm{MS}$ & $\mathbf{1}$ & $\mathbf{2}$ & $\mathbf{4}$ & $\mathbf{8}$ & $\mathbf{1 6}$ & $\mathbf{1}$ & $\mathbf{2}$ & $\mathbf{4}$ & $\mathbf{8}$ & $\mathbf{1 6}$ \\
\hline $\mathbf{1}$ & 5 & 10 & 20 & 40 & 80 & 8 & 16 & 32 & 64 & 128 \\
$\mathbf{3}$ & 15 & 30 & 60 & 120 & 240 & 24 & 48 & 96 & 192 & 384 \\
$\mathbf{6}$ & 30 & 60 & 120 & 240 & 480 & 48 & 96 & 192 & 384 & 768 \\
$\mathbf{9}$ & 45 & 90 & 180 & 360 & 720 & 72 & 144 & 288 & 576 & 1152 \\
$\mathbf{1 2}$ & 60 & 120 & 240 & 480 & 960 & 96 & 192 & 384 & 768 & 1536
\end{tabular}

\begin{tabular}{|c|c|}
\hline$[1 ; 30[$ & Insignificante \\
\hline$[30 ; 60[$ & Baixo \\
\hline$[60 ; 120[$ & Moderado \\
\hline$[120 ; 360[$ & Elevado \\
\hline$\geq 360$ & Excepcional \\
\hline
\end{tabular}

\subsection{Mapeamento e fluxo do processo do SAR de VilaReal}

O conhecimento pormenorizado do uso do solo é um elemento essencial para o desenvolvimento de um PSAR, nomeadamente para a identificação dos perigos, eventos perigosos e risco a que os diferentes grupos podem estar expostos. Por outro lado, permitenos avaliar a magnitude de cada subgrupo, nomeadamente os que se encontram relacionados com as práticas agrícolas (cerca de $63 \%$ ) e uso indistinto do meio hídrico recetor. Nesse sentido, foi analisado cada tipo de 
ocupação predominante do solo e definida uma faixa do rio Corgo (com $1000 \mathrm{~m}$ ) considerada com influência direta no risco associado às atividades das povoações ribeirinhas e ao uso de águas para fins agrícolas, com potencial efeito de descargas de águas residuais (tratadas ou não). Esta área de influência do meio hídrico que interage com o SARVR corresponde a cerca de $6090 \mathrm{ha}$, desenvolvendo-se ao longo de $23 \mathrm{~km}$, desde a ETAR de Vila Real até à confluência do rio Corgo com o rio Douro.
De acordo com a metodologia apresentada, procedeu-se ao mapeamento do sistema (Figura 10), de modo a permitir uma análise detalhada de todos os processos que constituem o SAR de Vila Real, bem como identificar as frações de resíduos (líquidos, sólidos e gasosos) e os grupos expostos aos diversos perigos, em cada local, para posterior avaliação do nível do risco dessa exposição.

Figura 10 - Mapeamento do Sistema de Águas Residuais de Vila Real (SARVR)

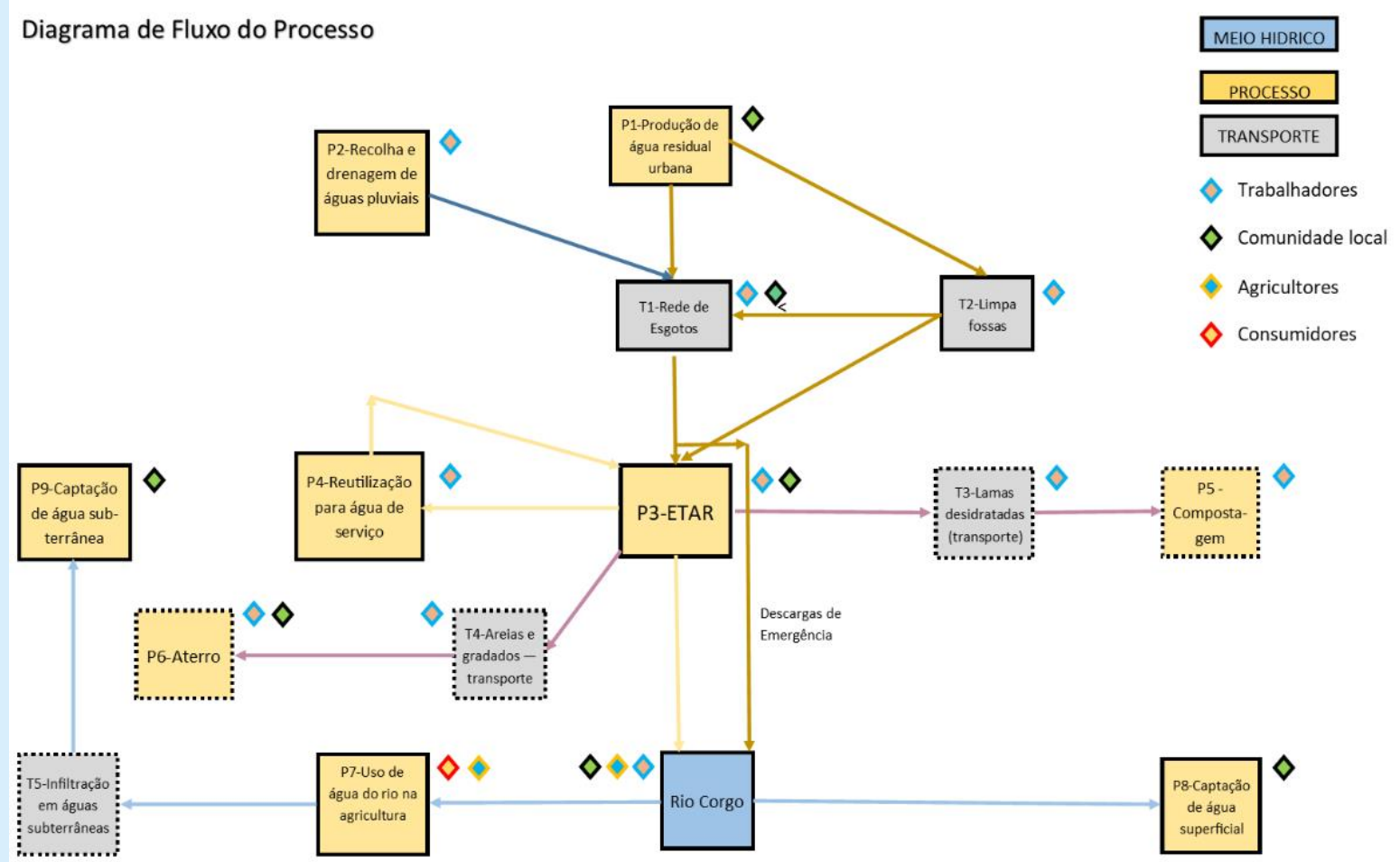

\subsection{Perigos, eventos perigosos e nível do risco no SAR de Vila Real}

Após o mapeamento com a identificação do fluxo de processos, as frações de resíduos e a dimensão dos grupos e subgrupos expostos, procedeu-se à identificação dos eventos perigosos e perigos relacionados com o SARVR, de modo a realizar a subsequente análise e avaliação do risco, visando detetar os eventos perigosos considerados como críticos para este sistema.

Os resultados obtidos encontram-se sintetizados na Figura 11, podendo ser consultados com maior detalhe em Pinto (2018) (Anexo B). Face à falta de históricos de dados (existentes ou conhecidos), será necessário, no futuro (numa fase de revisão do PSAR), revisitar a identificação de eventos perigosos efetuada, dada a sua importância para a plena eficácia deste plano. 
Figura 11- Identificação de perigos, eventos perigosos e avaliação do risco no SAR de Vila Real

\begin{tabular}{|c|c|c|c|c|c|c|c|c|c|c|}
\hline \multirow[b]{2}{*}{$\begin{array}{l}\text { ETAPA } \\
\text { (1) }\end{array}$} & \multicolumn{5}{|c|}{ Identificação do Perigo } & \multicolumn{5}{|c|}{ Avaliação de Risco } \\
\hline & $\begin{array}{c}\text { Tipo } \\
\text { de } \\
\text { Risco } \\
(2)\end{array}$ & $\begin{array}{l}\text { Grupo } \\
\text { Exposto }\end{array}$ & Evento Perigoso & Perigo & $\begin{array}{l}\text { Via de } \\
\text { Exposição }\end{array}$ & $\begin{array}{l}\text { Prob. } \\
\text { (3) }\end{array}$ & $\begin{array}{l}\text { Sev. } \\
(4)\end{array}$ & $\begin{array}{l}\text { Magn. } \\
(5)\end{array}$ & $\begin{array}{l}\text { Pont. } \\
(6)\end{array}$ & $\begin{array}{l}\text { Nivel } \\
\text { Risco } \\
\text { (7) }\end{array}$ \\
\hline P1 & B & $\mathrm{R} 2$ & $\begin{array}{l}\text { Exposição ao esgoto na sequência } \\
\text { de roturas ou colapsos na via } \\
\text { pública }\end{array}$ & $\begin{array}{l}\text { Microrganismos } \\
\text { patogénicos }\end{array}$ & contato & 3 & 2 & 1 & 6 & Insig. \\
\hline P1 & B & $\mathrm{C} 1$ & $\begin{array}{l}\text { Exposição ao esgoto em tarefas } \\
\text { de reparações da rede de } \\
\text { drenagem }\end{array}$ & $\begin{array}{l}\text { Microrganismos } \\
\text { patogénicos }\end{array}$ & contato & 3 & 2 & 6 & 36 & B \\
\hline P2 & Q & $\mathrm{C} 1$ & $\begin{array}{l}\text { Esposição ao esgoto pluvial em } \\
\text { tarefas de desobstruções e } \\
\text { limpezas de coletores e orgãos de } \\
\text { recolha }\end{array}$ & Quimicos tóxicos & $\begin{array}{l}\text { Inalação ou } \\
\text { ingestão }\end{array}$ & 3 & 2 & 3 & 18 & Insig. \\
\hline $\mathrm{T} 1$ & B & $\mathrm{C} 1$ & Exposição ao esgoto em tarefas & $\begin{array}{l}\text { Microrganismos } \\
\text { patogénicos }\end{array}$ & contato & 2 & 4 & 3 & 24 & Insig. \\
\hline $\mathrm{T} 1$ & Q & $\mathrm{C} 1$ & $\begin{array}{l}\text { de rotina no interior das caixas de } \\
\text { visita e estações elevatórias }\end{array}$ & $\begin{array}{c}\text { Quimico - } \\
\text { Existência de Gases } \\
\text { Tóxicox } \\
\end{array}$ & Inalação & 2 & 8 & 3 & 48 & B \\
\hline $\mathrm{T} 1$ & B & $\mathrm{C} 1$ & $\begin{array}{l}\text { Exposição ao esgoto em } \\
\text { ocorrências de obstrução de }\end{array}$ & $\begin{array}{l}\text { Microrganismos } \\
\text { patogénicos }\end{array}$ & $\begin{array}{c}\text { contato (pele e } \\
\text { olhos) }\end{array}$ & 3 & 8 & 6 & 144 & $\mathrm{E}$ \\
\hline $\mathrm{T} 1$ & $\mathrm{~F}$ & $\mathrm{C} 1$ & coletores. & Objetos Perfurantes & $\begin{array}{c}\text { Penetração na } \\
\text { pele }\end{array}$ & 2 & 8 & 6 & 96 & M \\
\hline $\mathrm{T} 1$ & B & $\mathrm{C} 1$ & Exposição ao esgoto em tarefas & $\begin{array}{l}\text { Microrganismos } \\
\text { patogénicos }\end{array}$ & contato & 3 & 4 & 6 & 72 & M \\
\hline $\mathrm{T} 1$ & Q & $\mathrm{C} 1$ & interior de Estações Elevatórias & $\begin{array}{c}\text { Quimico - } \\
\text { Existência de Gases } \\
\text { Tóxicox }\end{array}$ & Inalação & 2 & 8 & 6 & 96 & M \\
\hline $\mathrm{T} 1$ & B & $\mathrm{C} 1$ & $\begin{array}{l}\text { Colheita de amostras para } \\
\text { controlo de qualidade e controlo } \\
\text { operacional }\end{array}$ & $\begin{array}{l}\text { Microrganismos } \\
\text { patogénicos }\end{array}$ & contato & 3 & 4 & 3 & 36 & B \\
\hline $\mathrm{T} 1$ & B & $\mathrm{C} 1$ & Queda em poços de estações & $\begin{array}{c}\text { Microrganismos } \\
\text { patogénicos }\end{array}$ & $\begin{array}{c}\text { contato/Ingestã } \\
\mathrm{o}\end{array}$ & 2 & 16 & 6 & 192 & E \\
\hline $\mathrm{T} 1$ & $\mathrm{~F}$ & $\mathrm{C} 1$ & elevatórias & Afogamento & Ingestão & 2 & 16 & 6 & 192 & E \\
\hline $\mathrm{T} 1$ & $\mathrm{~F}$ & $\mathrm{C} 1$ & $\begin{array}{l}\text { Exposição ao esgoto em tarefas } \\
\text { de limpeza de grades mecânicas } \\
\text { em Estações Elevatórias }\end{array}$ & Objetos Perfurantes & $\begin{array}{c}\begin{array}{c}\text { Penetração na } \\
\text { pele }\end{array} \\
\text {. }\end{array}$ & 3 & 8 & 3 & 72 & M \\
\hline
\end{tabular}

Da análise do risco efetuada aos perigos e eventos perigosos identificados no SAR de Vila Real, concluiu-se que cerca de $50 \%$ dos eventos perigosos estão a montante da ETAR, justificando-se pela dimensão e estrutura do sistema de coleta e transporte, e que cerca de $70 \%$ dos eventos envolvem os colaboradores (internos e externos) da entidade gestora do sistema. Esta situação pode ser justificada pelas caraterísticas da comunidade local a jusante da ETAR, nomeadamente a dimensão do grupo dos consumidores e dos agricultores com práticas agrícolas de risco.

Destaca-se, ainda, a existência de um reduzido número de perigos e eventos perigosos com nível de risco "elevado", bem como a inexistência do nível "excecional".

Com base num estudo existente sobre a "Avaliação da concentração de microrganismos em suspensão na atmosfera do ar interior bactérias" na ETAR de Vila Real (RIBEIRO, 2017), foi possível identificar as zonas críticas onde ocorrem as maiores concentrações de bactérias nos diversos locais em que foi efetuada a monitorização: órgãos de entrada, tanque de arejamento, zona de deposição de lamas, descarga do efluente tratado e envolvente exterior à ETAR. Nestes locais, foram registados valores de 8707, 400, 2280, 5910 e $180\left(\mathrm{UFC} / \mathrm{m}^{3}\right)$ respetivamente, pelo que a obra de entrada é o 
local da ETAR que oferece maior perigo de contaminação por contato ou inalação.

3.4. Identificação de eventos perigosos críticos, medidas de controle e plano de melhorias

Da análise dos resultados globais da avaliação do risco, é possível identificar os eventos perigosos com níveis de risco críticos (classificações iguais ou superiores a "elevado"), considerados como inaceitáveis, de modo a serem propostas e implementadas medidas para controle (redução) do risco, sujeitas a posterior avaliação e eventual adaptação ou substituição.

Os eventos perigosos com nível do risco "elevado" abrangem, em grande parte, o grupo dos colaboradores que operam o SARVR, os quais, apesar de terem uma probabilidade de ocorrência reduzida, apresentam severidades maiores.

Estas situações encontravam-se já referenciadas nos procedimentos da própria entidade gestora, havendo a preocupação de garantir a realização das tarefas mais perigosas em equipa e não individualmente. Já no que respeita aos consumidores e agricultores, o nível do risco é mais influenciado pela probabilidade da ocorrência, que, obviamente, carece duma monitorização futura mais sistemática, de modo a obter um conjunto de dados mais consistentes.

$\mathrm{Na}$ Figura 12 apresenta-se a síntese dos eventos críticos (de nível "elevado") no SAR de Vila Real, bem como as medidas de controle correspondentes a cada um deles.

No que se refere aos eventos perigosos de caráter biológico, a eficácia das medidas alternativas propostas para a redução do risco deverá ser quantificada em termos de redução logarítmica, de acordo com as recomendações normativas da OMS (2015), relativas ao uso de águas residuais na agricultura.

Seguindo as diretrizes gerais anteriormente referidas, foi desenvolvido um Plano de Melhorias no sentido de reduzir o nível do risco de eventos perigosos críticos, para uma articulação e enquadramento das medidas de controle descritas e sistematizadas na Figura 13.

Figura 12 - Eventos perigosos com risco elevado no SARVR e suas medidas de controle

\begin{tabular}{|c|c|c|c|c|c|c|c|c|c|c|c|c|}
\hline \multirow[b]{2}{*}{$\begin{array}{l}\text { ETAPA } \\
\text { (1) }\end{array}$} & \multicolumn{5}{|c|}{ Identificação do Perigo } & \multicolumn{5}{|c|}{ Avaliação de Risco } & \multicolumn{2}{|c|}{ Medidas de Controle } \\
\hline & \begin{tabular}{|c|} 
Tipo \\
de \\
Risco \\
$(2)$
\end{tabular} & $\begin{array}{c}\text { Grupo } \\
\text { Exposto }\end{array}$ & Evento Perigoso & Perigo & $\begin{array}{l}\text { Via de } \\
\text { Exposição }\end{array}$ & $\begin{array}{l}\text { Prob. } \\
\text { (3) }\end{array}$ & $\begin{array}{l}\text { Sev. } \\
(4)\end{array}$ & $\begin{array}{l}\text { Magn. } \\
(5)\end{array}$ & $\begin{array}{l}\text { Pont. } \\
\text { (6) }\end{array}$ & $\begin{array}{l}\text { Nivel } \\
\text { Risco } \\
\text { (7) }\end{array}$ & $\begin{array}{c}\text { Identificação da } \\
\text { medida de controlo } \\
\text { existente(s) }\end{array}$ & Validação \\
\hline $\mathrm{T} 1$ & B & $\mathrm{C} 1$ & $\begin{array}{l}\text { Exposição ao esgoto em } \\
\text { ocorrências de obstrução de } \\
\text { coletores. }\end{array}$ & $\begin{array}{l}\text { Microrganismos } \\
\text { patogénicos }\end{array}$ & $\begin{array}{l}\text { contato } \\
\text { (pele e } \\
\text { olhos) }\end{array}$ & 3 & 8 & 6 & 144 & $\mathrm{E}$ & $\begin{array}{l}\text { Luvas, fato de } \\
\text { trabalho e botas }\end{array}$ & Visual \\
\hline $\mathrm{T} 1$ & B & $\mathrm{C} 1$ & $\begin{array}{l}\text { Queda em poços de estações } \\
\text { elevatórias }\end{array}$ & $\begin{array}{l}\text { Microrganismos } \\
\text { patogénicos }\end{array}$ & $\begin{array}{c}\text { contato/Inge } \\
\text { stão }\end{array}$ & 2 & 16 & 6 & 192 & $\mathrm{E}$ & $\begin{array}{l}\text { Trabalho em equipa } \\
\text { em espaços } \\
\text { confinados }\end{array}$ & $\begin{array}{l}\text { Visual, } \\
\text { procedimentos } \\
\text { internos e } \\
\text { formação }\end{array}$ \\
\hline $\mathrm{T} 1$ & $\mathrm{~F}$ & $\mathrm{C} 1$ & $\begin{array}{l}\text { Queda em poços de estações } \\
\text { elevatórias }\end{array}$ & Afogamento & Ingestão & 2 & 16 & 6 & 192 & $\mathrm{E}$ & $\begin{array}{l}\text { Trabalho em equipa } \\
\text { em espaços } \\
\text { confinados }\end{array}$ & $\begin{array}{l}\text { Visual, } \\
\text { procedimentos } \\
\text { internos e } \\
\text { formação }\end{array}$ \\
\hline P3 & Q & $\mathrm{C} 2 / \mathrm{C} 3$ & $\begin{array}{l}\text { Exposição ao contato com lamas } \\
\text { em tarefas de operação e transfega }\end{array}$ & $\begin{array}{l}\text { Quimicos tóxicos e } \\
\text { metais pesados }\end{array}$ & $\begin{array}{l}\text { Inalação e } \\
\text { ingestão }\end{array}$ & 3 & 8 & 6 & 144 & $\mathrm{E}$ & $\begin{array}{l}\text { Luvas, fato de } \\
\text { trabalho e botas }\end{array}$ & Visual \\
\hline P3 & Q & $\mathrm{C} 2 / \mathrm{C} 3$ & $\begin{array}{l}\text { Exposição ao contato com areias, } \\
\text { gradados e gorduras em tarefas de } \\
\text { operação e transfega }\end{array}$ & $\begin{array}{l}\text { Quimicos tóxicos e } \\
\text { metais pesados }\end{array}$ & $\begin{array}{l}\text { Inalação e } \\
\text { ingestão }\end{array}$ & 3 & 8 & 6 & 144 & $\mathrm{E}$ & $\begin{array}{l}\text { Luvas, fato de } \\
\text { trabalho e botas }\end{array}$ & Visual \\
\hline P7 & B & A1 & $\begin{array}{l}\text { Utilização de água do rio para uso } \\
\text { na agricultura - rega pelo pé em } \\
\text { vala }\end{array}$ & $\begin{array}{l}\text { Microrganismos } \\
\text { patogénicos }\end{array}$ & $\begin{array}{l}\text { Inalação e } \\
\text { contato }\end{array}$ & 6 & 8 & 3 & 144 & $\mathrm{E}$ & Inexistente & n.a. \\
\hline P7 & B & $\mathrm{U} 2$ & $\begin{array}{l}\text { Consomem produtos agricolas } \\
\text { contaminados pela rega }\end{array}$ & $\begin{array}{l}\text { Microrganismos } \\
\text { patogénicos }\end{array}$ & Ingestão & 6 & 8 & 3 & 144 & $\mathrm{E}$ & Inexistente & n.a. \\
\hline
\end{tabular}

As medidas de controle a implementar, relativas à maioria dos eventos com nível do risco "elevado", têm um impacto económico reduzido, pelo que o seu custo-benefício será certamente bastante positivo. Além disso, o fato de cerca de $75 \%$ das medidas preconizadas no Plano de Melhorias envolverem os colaboradores da entidade gestora, permite agilizar facilmente a 
sua implementação. Destaca-se, neste tipo de medidas, a utilização de máscaras e óculos de proteção e a realização de um programa de sensibilização sobre os perigos para a saúde decorrentes de exposições a substâncias perigosas sem os necessários equipamentos de proteção (PINTO, 2018).

Figura 13 - Plano de Melhoria proposto para o SAR de Vila Real

\begin{tabular}{|c|c|c|c|c|c|c|c|c|c|}
\hline \multirow[b]{2}{*}{ ETAPA } & \multicolumn{2}{|c|}{ Identificação do Perigo } & \multirow{2}{*}{$\begin{array}{c}\text { Nivel } \\
\text { do } \\
\text { Risco }\end{array}$} & \multicolumn{6}{|c|}{ Alternativas para o plano de melhoria } \\
\hline & \begin{tabular}{|c|} 
Grupo \\
Expost \\
0
\end{tabular} & Evento Perigoso & & Medida de controle possivel & Comentários & $\begin{array}{c}\text { Eficácia da } \\
\text { alternativa na } \\
\text { redução do risco }\end{array}$ & $\begin{array}{c}\text { Referência/valida } \\
\text { ção }\end{array}$ & Prioridade & Responsável \\
\hline $\mathrm{T} 1$ & $\mathrm{C} 1$ & \begin{tabular}{|l} 
Exposição ao \\
esgoto em \\
ocorrências de \\
obstrução de \\
coletores
\end{tabular} & $\mathrm{E}$ & $\begin{array}{l}\text { Garantia da qualidade dos EPI's } \\
\text { utilizados, nomeadamente de luvas } \\
\text { de proteção biológica. Utilização } \\
\text { de óculos de proteção no decurso } \\
\text { da operação de desobstrução. }\end{array}$ & $\begin{array}{l}\text { Este risco foi considerado elevado pela } \\
\text { possibilidade de projeção de microrganismos } \\
\text { para os olhos. }\end{array}$ & $\begin{array}{l}\text { Não quantificada, } \\
\text { mas terá efeitos } \\
\text { positivos } \\
\text { importantes. }\end{array}$ & $\begin{array}{l}\text { PRO 014 - } \\
\text { Preparação e } \\
\text { resposta a } \\
\text { emergências }\end{array}$ & $\begin{array}{l}\text { curto } \\
\text { prazo }\end{array}$ & AdNorte \\
\hline $\mathrm{T} 1$ & $\mathrm{C} 1$ & $\begin{array}{l}\text { Queda em poços de } \\
\text { estações } \\
\text { elevatórias. }\end{array}$ & $\mathrm{E}$ & $\begin{array}{l}\text { Garantir de que o trabalho é feito } \\
\text { em equipa. Disponibilizar botas } \\
\text { antiderrapantes. Utilizar arnês de } \\
\text { segurança. }\end{array}$ & $\begin{array}{l}\text { Necessário verificar se a queda não poderá } \\
\text { ser provocada por ambiente tóxico no interior } \\
\text { do poço. Esta situação é abrangida pela } \\
\text { medida de controle inicial que deve respeitar } \\
\text { o procedimento de trabalho em espaços } \\
\text { confinados }\end{array}$ & $\begin{array}{l}\text { Espera-se eficácia } \\
\text { elevada pela } \\
\text { redundância de } \\
\text { meios de segurança. }\end{array}$ & $\begin{array}{l}\text { Pro - Trabalhos } \\
\text { em espaços } \\
\text { confinados. } \\
\text { Correta e } \\
\text { adequada } \\
\text { utilização de } \\
\text { EPI's }\end{array}$ & $\begin{array}{l}\text { curto } \\
\text { prazo }\end{array}$ & AdNorte \\
\hline P3 & $\mathrm{C} 2 / \mathrm{C} 3$ & $\begin{array}{l}\text { Exposição ao } \\
\text { contato com lamas } \\
\text { em tarefas de } \\
\text { operação e } \\
\text { transfega. }\end{array}$ & E & $\begin{array}{l}\text { Sensibilização dos colaboradores. } \\
\text { Utilização de máscaras de } \\
\text { proteção. }\end{array}$ & $\begin{array}{l}\text { Consideram-se de grande importância as } \\
\text { ações de sensibilização dado o } \\
\text { desconhecimento do teor de materias tóxicos } \\
\text { e metais pesados existentes neste sub } \\
\text { produtos. Negligencia-se por vezes o seu } \\
\text { manuseamento. }\end{array}$ & $\begin{array}{l}\text { Não quantificada, } \\
\text { mas terá efeitos } \\
\text { positivos } \\
\text { importantes. }\end{array}$ & $\begin{array}{l}\text { IT } 024 \text { - Boas } \\
\text { práticas de } \\
\text { higiene }\end{array}$ & $\begin{array}{l}\text { curto } \\
\text { prazo }\end{array}$ & AdNorte \\
\hline P3 & $\mathrm{C} 2 / \mathrm{C} 3$ & \begin{tabular}{|l|} 
Exposição ao \\
contato com \\
areias, gradados e \\
gorduras em tarefas \\
de operação e \\
transfega.
\end{tabular} & $\mathrm{E}$ & $\begin{array}{l}\text { Sensibilização dos colaboradores. } \\
\text { Utilização de máscaras de } \\
\text { proteção. }\end{array}$ & $\begin{array}{l}\text { Consideram-se de grande importância as } \\
\text { ações de sensibilização dado o } \\
\text { desconhecimento do teor de materias tóxicos } \\
\text { e metais pesados existentes nestes sub } \\
\text { produtos. Negligencia-se por vezes o seu } \\
\text { manuseamento. }\end{array}$ & $\begin{array}{l}\text { Não quantificada, } \\
\text { mas terá efeitos } \\
\text { positivos } \\
\text { importantes. }\end{array}$ & $\begin{array}{l}\text { IT } 024 \text { - Boas } \\
\text { práticas de } \\
\text { higiene }\end{array}$ & $\begin{array}{l}\text { curto } \\
\text { prazo }\end{array}$ & AdNorte \\
\hline P7 & A1 & $\begin{array}{l}\text { Utilização de água } \\
\text { do rio para uso na } \\
\text { agricultura - rega } \\
\text { pelo pé em vala. }\end{array}$ & $\mathrm{E}$ & $\begin{array}{l}\text { Alterar o tipo de rega; e.g (gota a } \\
\text { gota ou micro aspersão). Uso de } \\
\text { vestuário de proteção pelo } \\
\text { agricultor e sensibilização para } \\
\text { boas práticas de higiene. }\end{array}$ & $\begin{array}{l}\text { Utilizar no minimo calçado adequado e luvas } \\
\text { de proteção biológica. No que respeita a } \\
\text { práticas de higiene é essencial mudar de } \\
\text { roupa antes das refeições ou quando próximo } \\
\text { de outras pessoas em ambiente fechado. }\end{array}$ & \begin{tabular}{|l|} 
Dificil aplicação pelo \\
investimento \\
necessário e \\
motivação dos \\
agricultores. Se \\
aplicado tem \\
impacto positivo \\
importante
\end{tabular} & $\begin{array}{l}\text { Guias da OMS } \\
2006 \text { - Vol } 2\end{array}$ & $\begin{array}{l}\text { Médio } \\
\text { prazo }\end{array}$ & $\begin{array}{l}\text { Associações de } \\
\text { Agricultores e } \\
\text { Autoridade } \\
\text { Local de Saúde }\end{array}$ \\
\hline P7 & $\mathrm{U} 2$ & $\begin{array}{l}\text { Consomem } \\
\text { produtos agricolas } \\
\text { contaminados pela } \\
\text { rega. }\end{array}$ & $\mathrm{E}$ & \begin{tabular}{|l} 
Campanhas de informação e \\
sensibilização dirigida aos \\
potenciais consumidores, \\
nomedamente sobre a confeção \\
dos produtos
\end{tabular} & $\begin{array}{l}\text { Muito importante a identificação dos } \\
\text { produtos mais perigosos, nomeadamente } \\
\text { vegetais para consumir em cru }\end{array}$ & \begin{tabular}{|l|} 
Dificil aplicação pela \\
preferência em \\
adquirir produtos \\
diretamente do \\
agricultor.
\end{tabular} & $\begin{array}{l}\text { Boas práticas de } \\
\text { higiene }\end{array}$ & $\begin{array}{l}\text { Médio } \\
\text { prazo }\end{array}$ & $\begin{array}{l}\text { Associações de } \\
\text { Agricultores e } \\
\text { Autoridade } \\
\text { Local de Saúde }\end{array}$ \\
\hline
\end{tabular}

Como é recomendado para qualquer plano de ação, há necessidade de monitorização e avaliação contínua da eficácia das medidas de controle implementadas, no sentido de propor futuras adaptações ou ações completares das mesmas (PINTO, 2018). Nesse sentido, recomenda-se a elaboração de um plano de monitorização detalhada a incorporar nos PSAR.

Os resultados da campanha de monitoramento realizada para avaliação da situação de referência relativa à qualidade da água no meio hídrico receptor permitiram verificar que, em situações severas de estiagem (vazões muito reduzidas), os teores de OD são baixos e existem trechos do rio sujeitos a processos de eutrofização, os quais podem ser potenciados pela carga orgânica e por nutrientes provenientes dos efluentes das ETAR (DUARTE, 2006).

$\mathrm{Na}$ avaliação bacteriológica, verificou-se um nível significativo na concentração de coliformes fecais em alguns trechos do rio a jusante das descargas, tendo-se observado 19 valores superiores ao valor máximo admissível (VMA) de
100 UFC/100 mL, para águas com utilização para rega, verificando-se um máximo de 2800 UFC/100 ml a jusante da descarga da ETAR de $S$. Miguel de Lobrigos. Tal situação correspondeu a um período de não operação (para manutenção) dos sistemas de desinfeção (radiação UV) das ETAR de Vila Real e de Vila Pouca de Aguiar.

Em campanha de amostragem posterior, já com esses sistemas em pleno funcionamento, verificou-se uma redução drástica dessas concentrações, evidenciando a importância do sistema terciário na mitigação deste risco para a saúde e o ambiente.

\section{CONCLUSÕES}

O trabalho desenvolvido permite concluir que nos PSAR a gestão do risco baseada numa estratégia que promove a existência de múltiplas barreiras para evitar a contaminação de vários grupos e produtos, numa lógica de conjunto, permite uma abordagem setorial e estratificada do 
PSAR, bem como a melhoria progressiva da mitigação do nível do risco, objetivo primordial em qualquer plano.

A introdução de mais um fator na metodologia de cálculo do nível de risco, a magnitude, constitui um desenvolvimento importante, por permitir considerar o efeito da dimensão real de cada um dos vários subgrupos expostos a um determinado evento perigoso e não necessariamente à totalidade do grupo, o que confere à avaliação do risco maior flexibilidade e fiabilidade.

Da análise do risco efetuada aos perigos e eventos perigosos identificados no SAR de Vila Real, concluiu-se que cerca de $50 \%$ dos eventos perigosos estão a montante da ETAR e que cerca de $70 \%$ dos eventos envolvem os colaboradores da entidade gestora do sistema.

A maioria das medidas de controle a implementar no SAR de Vila Real, para mitigação da maioria dos eventos com elevado nível do risco, envolve os colaboradores da entidade gestora, permitindo agilizar a sua implementação e adequada monitorização. Porém, as que envolvem os grupos dos agricultores e consumidores serão de difícil implementação por falta de sensibilização dos mesmos, sendo a intervenção da Autoridade de Saúde um contributo decisivo e crucial na minimização dos elevados níveis do risco desses eventos, face à sua maior proximidade e interação com as populações.

A avaliação dos principais parâmetros microbiológicos deve ser aprofundada, para cada área geográfica, em função da caraterização das populações e das diversas atividades que aí se desenvolvem (agrícola, pecuária, industrial).

$\mathrm{Na}$ sequência da abordagem feita às restantes ETAR da bacia do Corgo, concluiu-se ser fundamental que os planos de segurança tenham uma estratégia/vertente integradora de todos os contribuintes para a bacia hidrográfica e não abordagens individualizadas (e.g., SAR de Vila Real), no sentido de não se negligenciar 0 efeito cumulativo dos impactos das descargas de esgotos no meio hídrico receptor.

O trabalho efetuado permite concluir que é benéfica e desejável quer a articulação de PSA com os PSAR, quer a integração dos sistemas em "baixa" com os sistemas em "alta", de modo a privilegiar abordagens holísticas na gestão do risco ao nível do ciclo urbano da água.

\section{REFERÊNCIAS}

ARAÚJO, M.; VIEIRA, J.M.P. Contributos para o desenvolvimento de um plano de segurança de saneamento na cidade de Braga. In: ENCONTRO DE ENGENHARIA SANITÁRIA E AMBIENTAL, 17., 2016, Lisboa. Anais do 17ํㅡㄹ ENASB. Ed. APESB, 2016.

AS/NZS - AUSTRALIA, NEW ZEALAND. AS/NZS 4360:2004 Risk management standard. 3. ed. Standard Australia and Standard New Zealand, 2004.

BARTRAM, J. Water safety plan manual: step-by-step risk management for drinking-water suppliers. Geneve: World Health Organization, 2009.

BEZERRA, N. R. Aplicação da técnica Delphi para validação dos métodos a serem utilizados no sistema em plataforma WEB para implantação de plano de segurança da água. GESTA, v. 6, n. 1, p. 29-40, 2018.

BOŽEK, F.; URBAN, R. Risk management - General Part. 145 p. 2008. Monografia (Graduação) - University of Defence, Brno, Czech Republic, 2008.

DUARTE, A. A. L. S. Impacto das alterações climáticas na gestão da água. Águas \& Resíduos, v. 3, n. 2, p. 58-73, 2007.

.Influência da hidrodinâmica em sistemas estuarinos sujeitos a eutrofização. 367 p. 2006. Tese (Doutorado) - Escola de Engenharia, Universidade do Minho, Braga, Portugal, 2006.

IPQ - PORTUGAL. NP ISSO 31000 Gestão do risco: princípios e linhas de orientação. Instituto Português da Qualidade, Lisboa, 2012,

MOK, H. F.; HAMILTON, A. J. Exposure factors for wastewater-irrigated Asian vegetables and probabilistic rotavirus disease burden model for their consumption. Risk Analysis, v. 34, p. 602-613, 2014.

OMS. Sanitation Safety Planning: manual for safe use and disposal of wastewater, greywater and excreta. Geneva, Switzerland, 2015.

Guidelines for Drinking-water Quality. 3. ed. World Health Organization, Geneva, Switzerland, 2004.

Water Safety Plan Manual - Step-by-step risk management for drinking- water suppliers. World Health Organization, Geneve, Switzerland, 2011.

Guidelines for the Safe Use of Wastewater,

Excreta and Greywater in Agriculture and 
Aquaculture. 3. ed. World Health Organization, Geneva, 2006.

PINTO, F. R. C. Contributo para o desenvolvimento de planos de segurança de águas residuais. $77 \mathrm{p}$. 2018. Dissertação (Mestrado) - Universidade de Coimbra, Coimbra, Portugal, 2018.

RIBEIRO, V. Avaliação da concentração de microrganismos em suspensão na atmosfera do ar interior - Bactérias. Relatório Técnico, LabLAR Laboratório de avaliação dos riscos, 2017, 10 p.

STENSTRÖN, T. A.; SEIDU, R.; EKANE, N.; ZURBRÜGG, C. Microbial exposure and health assessments in sanitation technologies and systems. Stockholm Environment Institute, EcoSanRes Series, 2011-1, 55 p.

VIEIRA, J. M. P; MORAIS, C. Guia Técnico 7 - Planos de Segurança da Água para Consumo Humano em Sistemas Públicos de Abastecimento. Publicação on-line da ERSAR, Portugal, 2005.

Water safety plans: methodologies for risk assessment and risk management in drinking-water systems. The Fourth Inter-Celtic Colloquium on Hydrology and Management of Water Resources, Guimarães, Portugal, 2005. 